\title{
PROFIL BERPIKIR SISWA SMA DENGAN TIPE KEPRIBADIAN CHOLERIS DALAM PEMECAHAN MASALAH MATEMATIKA DITINJAU DARI PERBEDAAN JENIS KELAMIN
}

\author{
Moh.Syukron Maftuh, S.Pd., M.Pd \\ Dosen Prodi Pendidikan Matematika-FKIP-Universitas PGRI Adi Buana Surabaya \\ mtu_hutfam@yahoo.co.id
}

\begin{abstract}
Abstrak
Penelitian ini bertujuan untuk mendeskripsikan profil berpikir siswa SMA dengan tipe kepribadian choleris dalam pemecahan masalah matematika ditinjau dari perbedaan jenis kelamin. Penelitian ini menggunakan penelitian eksploratif dengan pendekatan kualitatif. Hasil penelitian diperoleh bahwa subjek Laki-laki dalam memahami masalah: menuliskan apa yang diketahui menggunakan bahasa simbol dan yang ditanyakan menggunakan bahasa verbal, menyajikan konsep bilangan ke dalam bentuk aljabar, serta menyatakan bilangan tiga angka yang dicari ke dalam bentuk aljabar berdasarkan aturan nilai tempat. Ketika menyusun rencana, subjek Laki-laki mengingat masalah lain yang telah berhasil dipecahkan dan mirip dengan masalah yang diberikan, serta menghubungkan konsep-konsep yang ada pada kedua masalah tersebut. Pada saat melaksanakan rencana pemecahan masalah, subjek Laki-laki tidak terikat dengan cara yang telah disusun pada fase sebelumnya, tidak menjelaskan alasan langkah-langkah penyelesaian dapat diterapkan dan menyadari bahwa jawaban dari masalah yang diberikan merupakan gabungan dari nilai setiap variabel. Sedangkan ketika memeriksa kembali, subjek Laki-laki hanya mensubstitusikan hasil yang diperoleh ke persamaan/informasi yang ada pada masalah yang diberikan. Subjek Perempuan ketika memahami masalah mengungkapkan apa yang diketahui dan ditanyakan dengan menggunakan bahasa simbol, menyajikan konsep bilangan dan bilangan tiga angka yang dicari ke dalam bentuk aljabar. Sedangkan ketika menyusun rencana, subjek Perempuan mengingat masalah lain yang telah berhasil dipecahkan dan mirip dengan masalah yang diberikan, dan menghubungkan konsep-konsep yang ada pada kedua masalah tersebut. Ketika melaksanakan rencana pemecahan masalah, subjek perempuan melaksanakan rencana pemecahan masalah seperti yang telah disusun sebelumnya dengan menggunakan cara campuran (eliminasi dan substitusi) dan menjelaskan alasan langkah penyelesaian dapat diterapkan. Kemudian, ketika memeriksa kembali, subjek mensubstitusikan hasil yang diperoleh ke persamaan/informasi yang ada pada masalah yang diberikan serta mengingat kembali apa yang ditanyakan dan mencocokkannya dengan jawaban yang diperolehnya.
\end{abstract}

Kata kunci : Berpikir, Pemecahan Masalah Matematika, Tipe Kepribadain, Jenis Kelamin

\section{Pendahuluan}

Menurut Depdiknas (2006) mata pelajaran matematika perlu diberikan kepada semua peserta didik mulai dari Sekolah Dasar untuk membekali peserta didik dengan kemampuan berpikir logis, analitis, sistematis, kritis, dan kreatif serta kemampuan kerja sama. Adapun tujuan diberikannya mata pelajaran matematika di sekolah adalah diharapkan mengacu pada pemecahan masalah, sehingga pemecahan masalah perlu diajarkan mulai dari tingkat SD sampai tingkat SMA. Pehkonen (dalam Siswono, 2008) membagi menjadi 4 kategori alasan untuk mengajarkan pemecahan masalah, yaitu:

1.Pemecahan masalah mengembangkan keterampilan kognitif secara umum.

2.Pemecahan masalah mendorong kreativitas.

3.Pemecahan masalah merupakan proses aplikasi matematika.

4.Pemecahan masalah memotivasikan siswa untuk belajar matematika. 
Hudojo (2001) memecahkan masalah dalam pembelajaran matematika merupakan suatu keterampilan yang harus dimiliki siswa dalam menghadapi dunia yang tidak menentu. Oleh karena itu, setiap siswa perlu diberikan latihan pemecahan masalah agar siswa dapat berpikir logis, analitis, kritis dan kreatif dalam mengambil keputusan dan mengaplikasikannya dalam situasi yang berbeda.

Menurut Polya(1973) terdapat 4 tahap dalam pemecahan masalah, yaitu: (1) memahami masalah (understanding the problem), (2) membuat rencana penyelesaian (devise a plan), (3) melaksanakan rencana penyelesaian (carry out the plan), (4) memeriksa kembali penyelesaian (looking back). Sedangkan menurut Krulik dan Rudnick (dalam Siswono, 2008) langkah-langkah pemecahan masalah terdiri dari membaca dan berpikir (read and think), mengeksplorasi dan merencanakan (explore and plan), menyelesaikan suatu strategi (select a strategy), mencari suatu jawaban (find and answer), dan merefleksi dan memperluas (reflect and extend). Perhatikan bahwa tahap-tahap pemecahan masalah yang dibuat oleh Krulik dan Rudnick tidak jauh berbeda dengan tahaptahap pemecahan masalah Polya.

Pada penelitian ini tahap-tahap pemecahan masalah yang digunakan yaitu tahap Polya dengan alasan bahwa: (1) tahap-tahap yang dikemukakan Polya cukup sederhana; (2) perbedaan aktivitas-aktivitas yang menandai tiap-tiap tahap yang dikemukakan polya cukup jelas; dan (3) tahap-tahap pemecahan masalah Polya secara implisit mencakup semua tahaptahap pemecahan masalah yang dikemukakan oleh ahli lain seperti Krulik \& Rudnick.

Untuk dapat memecahkan masalah matematika dibutuhkan proses berpikir yang optimal. Proses berpikir adalah aktivitas kognitif siswa yang dimulai dari menerima masalah, menggunakan informasi yang telah ada sehingga didapatkan penyelesaian dari masalah matematika. Aktivitas kognitif yang terjadi disertai dengan ekpresi verbal siswa, yaitu siswa mengekspresikan ide mereka dengan berbicara ketika menyelesaikan soal pemecahan masalah. Solso (2008) menyatakan bahwa berpikir merupakan proses yang menghasilkan representasi mental yang baru melalui transformasi informasi yang melibatkan interaksi yang kompleks antara berbagai proses mental seperti penilaian, abstraksi, penalaran, imajinasi dan pemecahan masalah. Proses berpikir menghasilkan suatu pengetahuan baru yang merupakan transformasi informasiinformasi sebelumnya.

Proses berpikir siswa dalam menyelesaikan soal masalah matematika bisa dipengaruhi oleh beberapa faktor. Menurut Pimta, Tayruakham, dan Nuangchalerm (2009):

Factors influencing mathematic problemsolving ability were represented as following: direct factors influencing mathematic problemsolving ability were described that direct and indirect factors influencing mathematic problem-solving ability were attitude towards mathematics, self-esteem and teachers teaching behavior. Indirect factors influencing mathematic problem-solving ability were motivation and self-efficacy.

Dari uraian tersebut dikatakan bahwa faktor yang mempengaruhi kemampuan pemecahan masalah matematika adalah faktor langsung dan tidak langsung. Faktor tidak langsung yang mempengaruhi adalah motivasi dan kemampuan diri. Motivasi dan kemampuan diri merupakan faktor yang berasal dari dalam diri siswa sehingga dapat dipengaruhi oleh karakteristik yang dimiliki. Karakteristik siswa tersebut dapat dikatakan sebagai tipe kepribadian siswa.

Ada banyak teori yang dapat digunakan dalam memahami tipe kepribadian siswa. Salah satu teori yang sering digunakan dan terus dikembangkan adalah teori kepribadian Tipologi Hippocrates-Galenus. Menurut Tipologi Hippocrates-Galenus, kepribadian 
digolongkan menjadi empat yaitu: choleris, sanguinis, melancholis, dan phlegmatis.

Dalam peneletian ini, peneliti hanya mengaji tentang kepribadian choleris saja, alasan peneliti mengaji tentang kepribadian choleris saja adalah karena dalam melakukan proses berpikir untuk mecahkan suatu masalah dibutuhkan kemauan yang kuat dan keras, tidak emosional dalam bertindak, berorientasi target, mencari pemecahan praktis, bergerak cepat untuk bertindak, mendelegasikan pekerjaan, membuat target, itu semua adalah ciri-ciri yang dimiliki siswa yang memiliki tipe kepribadian choleris seperti yang diuangkap Suryabrata (2010) menyatakan bahwa tipe kepribadian choleris ciri-cirinya dalam pekerjaan harus memperbaiki kesalahan, berkemauan kuat dan keras, tidak emosional dalam bertindak, berorientasi target, melihat seluruh gambaran, mencari pemecahan praktis, bergerak cepat untuk bertindak, mendelegasikan pekerjaan, menekankan pada hasil, membuat target, dan berkembang karena saingan

Peneliti juga menduga ada perbedaan berpikir antara siswa laki-laki dan siswa perempuan, pendapat ini sesuai dengan pendapat yang diutarakan Dewiyani (2012), "every personality types had different thinking process profil in problem solving was also different between male and female." Siswa dengan tipe kepribadian yang berbeda akan berbeda pula proses berpikirnya, selain itu proses berpikir antar siswa laki-laki dan perempuan juga mengalami perbedaan.

Berdasarkan uraian di atas, penulis tertarik untuk mengadakan penelitian tentang Profil berpikir siswa SMA dengan tipe kepribadian choleris dalam pemecahan masalah matematika ditinjau dari perbedaan jenis kelamin, adapun rumusan masalah penelitian ini adalah

a. Bagaimana profil berpikir siswa laki-laki dengan tipe kepribadian choleris dalam pemecahan masalah matematika? b. Bagaimana profil berpikir siswa perempuan dengan tipe kepribadian choleris dalam pemecahan masalah matematika?

\section{Metode Penelitian}

\section{Jenis penelitian}

Peneliti mempelajari dan mengungkap profil berpikir yang dilakukan oleh siswa dengan tipe kepribadian choleris melalui data hasil tes dan wawancara berbasis tugas. Berkenaan dengan berpikir yang dilakukan oleh siswa, akan dieksplorasi bagaimana berpikir oleh subjek dalam memahami masalah, merencanakan pemecahan masalah, melaksanakan rencana, dan bagaimana subjek melakukan refleksi atau menguji solusi yang diperoleh. Data utamanya berupa kata-kata tertulis atau lisan. Berdasarkan data tersebut akan diungkap profil berpikir yang dilakukan oleh subjek dalam pemecahan masalah matematika. Dengan demikian, penelitian ini dikatagorikan penelitian eksploratif dengan pendekatan kualitatif

\section{Subjek Penelitian}

Subyek penelitian ini adalah siswa SMA Intensif Taruna Pembangunan (ITP). Alasan peneliti memilih SMA Intensif Taruna Pembangunan sebagai subjek penelitian karena atas pertimbangan bahwa UNIPA sudah terjalin komunikasi yang baik dengan warga sekolah tersebut sehingga proses dalam perizinan lebih muda, serta alasan pemilihan siswa SMA kelas $\mathrm{X}$ sebagai subjek penelitian, dengan alasan: (1) siswa tersebut telah mendapatkan pembelajaran Sistem Persamaan Linier Dua Variabel Maupun Tiga Variabel, (2) siswa mempunyai cukup pengetahuan dan pengalaman dalam materimateri matematika dasar, karena telah melewati tingkat sekolah dasar dan kelas IX SMP yang sudah mempelajari materi-materi yang dibutuhkan siswa untuk mempelajari materi Sistem Persamaan Linier Dua Variabel Maupun Tiga Variabel, (3) siswa SMA kelas X dimungkinkan mampu mengomunikasikan 
berpikirnya secara lisan maupun tulisan, sehingga eksplorasi tentang bagaimana siswa berpikir dalam memecahkan masalah matematika akan dapat dilakukan.

Dan pemilihan subjek dalam penelitian ini dipilih minimal seorang laki-laki dan seorang perempuan. Ke-dua siswa tersebut memiliki tipe kepribadian Croloris dengan kemampuan matematika yang relatif sama. Informasi untuk menentukan tipe kepribadian Croloris, subjek akan diberi tes penentuan kepribadian, sedangkan informasi untuk menentukan kemampuan matematika diperoleh dari guru matematika yang mengajar subjek tersebut. Di samping itu juga, penentuan subjek juga memperhatikan kemampuan komunikasi subjek untuk mengemukakan pendapat atau jalan pikirannya secara lisan maupun tulisan. Pentingnya peneliti mempertimbangkan kemampuan komunikasi subjek, agar eksplorasi tentang bagaimana siswa berpikir dalam pemecahan masalah matematika dapat dilalukukan dengan baik. Apabila subjek tersebut belum mampu memberikan data yang memuaskan, maka peneliti mencari subjek lain lagi yang dapat digunakan sebagai subjek penelitian

\section{Instrumen penelitian}

instrumen utamanya yaitu peneliti sendiri, karena peneliti sendiri yang mengumpulkan, menganalisis, dan menginterpretasi data. Pada saat pengumpulan data peneliti menggunakan instrumen bantu yang berupa Tes Kepribadian, Tugas Pemecahan Masalah Matematiak (TPMM) pedoman wawancara, dan alat bantu rekam.

\section{Analisis dan penafsiran data}

Dalam penelitian ini, analisis data mengikuti alur kegiatan analisis data kualitatif menurut Miles dan Huberman (1992), bahwa analisis data kualitatif terdiri dari tiga alur kegiatan yang terjadi secara bersamaan yaitu reduksi data, penyajian data dan penarikan kesimpulan.

\section{a. Reduksi Data}

Adapun kegiatan yang dilakukan pada reduksi data adalah sebagai berikut:
1) Membuang transkip data hasil wawancara dan catatan lapangan saat subjek memecahkan masalah.

2) Memeriksa ulang kebenaran hasil transkip dengan memutar kembali rekaman untuk melihat perilaku dan mendengar ungkapanungkapan waktu wawancara.

3) Hasil transkip direduksi, yaitu dengan merangkum, menyeleksi, dan membuang dat-data yang tidak diperlukan, serta disederhanakan, dikelompokkan dan dikatagorikan berdasarkan indikatorindikator proses berpikir

\section{b. Penyajian Data}

Yang dilakukan dalam tahap penyajian data, yaitu mengklasifikasikan data dalam bentuk sekumpulan informasi yang terorganisasi dan terkatagori sehingga mempermuda dan memungkinkan peneliti membuat kesimpulan. Data akan didentifikasi berdasarkan indikatorindikator bernalar probabilistik.Sebelum data disimpulkan, data yang sudah disajikan baik dari hasil wawancara maupun hasil tugas pemecahan masalah matematika akan di lakukan triangulasi, triangulasi yang dipakai dalam penelitian ini adalah triangulasi waktu. Triangulasi waktu menurut Sugiyono (2011) adalah pengecekan derajat kepercayaan beberapa sumber data yang diperoleh pada waktu yang berbeda

Dengan demikian, pengumpulan data ini dilakukan minimal dua kali dengan tugas-tugas yang berbeda tetapi isi dari tugas tersebut cendrung sama. Hasil pekerjaan tulis dan wawancara menggunakan tugas ke-1 (data pertama) dibandingkan dengan hasil pekerjaan tulis dan wawancara menggunakan tugas ke-2 (data kedua). Jika data-data tersebut menunjukkan konsistensi, kesamaan pandangan dan pendapat, maka dapat dikatakan data-data tersebut valid, tetapi jika tidak, maka akan dilakukan pengambilan data ketiga. Pada pengambilan data ketiga, apabila data yang diperoleh sesuai dengan data pertama, maka 
Tahun XI, No. 20, April 2015

data pertama valid. Jika diperoleh data yang sesuai dengan yang kedua, maka data kedua tersebut valid. Jika ternyata diperoleh data yang tidak sesuai dengan salah satunya, maka dilakukan pengambilan data berikutnya. Demikian seterusnya sampai diperoleh data yang sesuai.

\section{c. Penarikan Simpulan}

Penarikan kesimpulan dilakukan berdasarkan penyajian data yang telah disajikan, yaitu penarikan simpulan untuk mengungkap profil berpikir subjek coleris dalam pemecahan masalah matematika ditinjau dari perbedaan jenis kelamin

\section{Hasil dan Pembahasan}

hasil penelitian ini mengungkap profil berpikir siswa SMA dengan tipe kepribadian choleris dalam pemecahan masalah matematika. Yang diperoleh dari paparan data tertulis dan paparan data wawancara subjek, kemudian dideskripsikan berdasarkan masing-masing masalah yang terdapat pada tugas pemecahan masalah matematika dan dilakukan validasi, berikut deskripsi dari paparan data penalaran probabilistik masing-masing masalah pada TPMP

\section{Diskripsi Berpikir Subjek Laki-Laki dalam Pemecahan Masalah Matematika}

a. Diskripsi berpikir subjek laki-laki dalam memahami maslah matematika

Tabel 1: Deskripsi berpikir subjek laki-laki dalam memahami masalah matematika

\begin{tabular}{|l|l|}
\hline \multicolumn{2}{|c|}{ Fase Memahami Masalah } \\
\hline \multicolumn{1}{|c|}{ Indikator } & \multicolumn{1}{c|}{ Deskripsi } \\
\hline $\begin{array}{l}\text { mengungkapka } \\
\text { n apa yang } \\
\text { diketahui dan } \\
\text { ditanyakan. }\end{array}$ & $\begin{array}{l}\text { Subjek menuliskan apa yang } \\
\text { diketahui dan ditanyakan. }\end{array}$ \\
\hline
\end{tabular}

\begin{tabular}{|c|c|}
\hline \multicolumn{2}{|c|}{ Fase Memahami Masalah } \\
\hline Indikator & Deskripsi \\
\hline $\begin{array}{l}\text { menghubungka } \\
\text { n konsep- } \\
\text { konsep yang } \\
\text { ada pada } \\
\text { masalah yang } \\
\text { diberikan. }\end{array}$ & $\begin{array}{l}\text { Subjek menyajikan konsep } \\
\text { bilangan ke dalam bentuk } \\
\text { aljabar. }\end{array}$ \\
\hline $\begin{array}{l}\text { merepresentasi } \\
\text { kannya dengan } \\
\text { gambar atau } \\
\text { notasi/simbol } \\
\text { yang cocok } \\
\text { dengan } \\
\text { menggunakan } \\
\text { penalaran yang } \\
\text { logis }\end{array}$ & $\begin{array}{l}\text { - Subjek menggunakan } \\
\text { notasi/simbol untuk } \\
\text { menyatakan informasi } \\
\text { yang diketahui. } \\
\text { - Subjek menyatakan } \\
\text { bilangan tiga angka yang } \\
\text { dicari ke dalam bentuk } \\
\text { aljabar karena bilangan } \\
\text { tiga angka merupakan } \\
\text { bilangan ratusan, } \\
\text { sehingga angka pertama } \\
\text { menempati nilai tempat } \\
\text { ratusan, angka kedua } \\
\text { menempati nilai tempat } \\
\text { puluhan dan angka } \\
\text { ketiga menempati nilai } \\
\text { tempat satuan. }\end{array}$ \\
\hline
\end{tabular}

b. Diskripsi berpikir subjek laki-laki dalam menyusun rencana pemcahan maslah matematika

Tabel 2: Deskripsi berpikir subjek laki-laki dalam menyusun rencana pemecahan masalah matematika

\begin{tabular}{|l|l|}
\hline \multicolumn{2}{|c|}{ Fase Menyusun Rencana } \\
\hline \multicolumn{1}{|c|}{ Indikator } & \multicolumn{1}{c|}{ Deskripsi } \\
\hline $\begin{array}{l}\text { Menyusun } \\
\text { rencana dengan } \\
\text { memperhatikan/ } \\
\text { mengingat } \\
\text { masalah lain } \\
\text { yang telah } \\
\text { berhasil }\end{array}$ & $\begin{array}{l}\text { Subjek menyatakan } \\
\text { pernah mendapatkan } \\
\text { masalah yang mirip } \\
\text { dengan masalah yang } \\
\text { diberikan. }\end{array}$ \\
\hline
\end{tabular}




\begin{tabular}{|l|l|}
\hline \multicolumn{2}{|c|}{ Fase Menyusun Rencana } \\
\hline \multicolumn{1}{|c|}{ Indikator } & \multicolumn{1}{c|}{ Deskripsi } \\
\hline $\begin{array}{l}\text { dipecahkan dan } \\
\text { mirip dengan } \\
\text { masalah yang } \\
\text { diberikan. }\end{array}$ & $\begin{array}{l}\text { berhasil digunakan } \\
\text { untuk menyelesaikan } \\
\text { masalah yang dulu } \\
\text { pernah diberikan. } \\
\text { Subjek menyusun } \\
\text { rencana penyelesaian } \\
\text { untuk masalah yang } \\
\text { diberikan saat ini } \\
\text { berdasarkan cara yang } \\
\text { telah berhasil } \\
\text { diterapkan. }\end{array}$ \\
$\begin{array}{l}\text { Menghubungkan } \\
\text { konsep-konsep } \\
\text { yang ada pada } \\
\text { masalah yang } \\
\text { diberikan } \\
\text { dengan konsep } \\
\text { yang ada pada } \\
\text { masalah yang } \\
\text { mirip dan telah } \\
\text { berhasil } \\
\text { dipecahkan } \\
\text { sebelumnya. }\end{array}$ & $\begin{array}{l}\text { konsep-konsep pada } \\
\text { masalah yang dulu dengan } \\
\text { masalah yang saat ini } \\
\text { diberikan. }\end{array}$ \\
\hline
\end{tabular}

\section{c. Diskripsi berpikir subjek laki-laki dalam melaksanakan rencana pemecahan maslah matematika}

Tabel 3: Deskripsi berpikir subjek laki-laki dalam melaksanakan rencana pemecahan masalah matematika

\begin{tabular}{|l|l|}
\hline \multicolumn{2}{|c|}{ Fase Melaksanakan Rencana } \\
\hline \multicolumn{1}{|c|}{ Indikator } & \multicolumn{1}{c|}{ Deskripsi } \\
\hline $\begin{array}{l}\text { Melaksanakan } \\
\text { rencana yang } \\
\text { telah dibuat } \\
\text { pada fase 2. }\end{array}$ & $\begin{array}{l}\text { Subjek tidak terikat } \\
\text { dengan rencana yang telah } \\
\text { disusun sebelumnya. }\end{array}$ \\
\hline
\end{tabular}

\section{d. Diskripsi berpikir subjek laki-laki dalam memeriksa solusi yang diperoleh}

Tabel 4: Deskripsi berpikir subjek laki-laki dalam memeriksa solusi yang diperoleh

\begin{tabular}{|c|c|}
\hline \multicolumn{2}{|c|}{ Fase Memeriksa Kembali } \\
\hline Indikator & Deskripsi \\
\hline $\begin{array}{l}\text { Memeriksa } \\
\text { jawaban yang } \\
\text { diperoleh } \\
\text { dengan } \\
\text { memperhatikan } \\
\text { apakah } \\
\text { langkah yang } \\
\text { diterapkan } \\
\text { sudah sesuai } \\
\text { dengan } \\
\text { prosedur yang } \\
\text { direncanakan. }\end{array}$ & $\begin{array}{l}\text { Subjek mensubstitusikan } \\
\text { hasil yang diperoleh ke } \\
\text { persamaan/informasi yang } \\
\text { ada pada masalah yang } \\
\text { diberikan. }\end{array}$ \\
\hline
\end{tabular}

2. Diskripsi Berpikir Subjek Perempuan dalam Pemecahan Masalah Matematika

a. Diskripsi berpikir subjek perempuan dalam memahami maslah matematika

Tabel 5: Deskripsi berpikir subjek perempuan dalam memahami masalah matematika

\begin{tabular}{|l|l|}
\hline \multicolumn{2}{|c|}{ Fase Memahami Masalah } \\
\hline \multicolumn{1}{|c|}{ Indikator } & \multicolumn{1}{|c|}{ Deskripsi } \\
\hline $\begin{array}{l}\text { mengungkap } \\
\text { kan apa yang } \\
\text { diketahui dan } \\
\text { ditanyakan. }\end{array}$ & $\begin{array}{l}\text { Subjek mengungkapkan apa } \\
\text { yang diketahui dan } \\
\text { ditanyakan. }\end{array}$ \\
\hline $\begin{array}{l}\text { menghubung } \\
\text { kan konsep- } \\
\text { konsep yang } \\
\text { ada pada } \\
\text { masalah yang } \\
\text { diberikan. }\end{array}$ & $\begin{array}{l}\text { Subjek menyajikan konsep } \\
\text { bilangan ke dalam bentuk } \\
\text { aljabar. }\end{array}$ \\
\hline $\begin{array}{l}\text { merepresenta } \\
\text { sikannya } \\
\text { dengan } \\
\text { gambar atau } \\
\text { notasi/simbol }\end{array}$ & $\begin{array}{l}\text { - Subjek menggunakan } \\
\text { notasi/simbol untuk } \\
\text { menyatakan informasi } \\
\text { yang diketahui dan } \\
\text { ditanyakan. }\end{array}$ \\
\hline
\end{tabular}


Tahun XI, No. 20, April 2015

\begin{tabular}{|l|l|}
\hline \multicolumn{2}{|c|}{ Fase Memahami Masalah } \\
\hline \multicolumn{1}{|c|}{ Indikator } & \multicolumn{1}{|c|}{ Deskripsi } \\
\hline yang cocok & - $\begin{array}{l}\text { Subjek menyatakan } \\
\text { bilangan tiga angka yang } \\
\text { dengan }\end{array}$ \\
menggunaka & $\begin{array}{l}\text { dicari ke dalam bentuk } \\
\text { aljabar karena bilangan } \\
\text { n penalaran } \\
\text { yang logis }\end{array}$ \\
& bilangan ratusan. \\
\hline
\end{tabular}

\section{b. Diskripsi berpikir subjek perempuan dalam menyusun rencana pemcahan maslah matematika}

Tabel 6: Deskripsi berpikir subjek perempuan dalam menyusun rencana pemecahan masalah matematika

\begin{tabular}{|l|l|}
\hline \multicolumn{2}{|c|}{ Fase Menyusun Rencana } \\
\hline \multicolumn{1}{|c|}{ Indikator } & \multicolumn{1}{|c|}{ Deskripsi } \\
\hline $\begin{array}{l}\text { Menyusun } \\
\text { rencana dengan } \\
\text { memperhatikan/ } \\
\text { mengingat } \\
\text { masalah lain } \\
\text { yang telah } \\
\text { berhasil } \\
\text { dipecahkan dan } \\
\text { mirip dengan } \\
\text { masalah yang } \\
\text { diberikan. }\end{array}$ & $\begin{array}{l}\text { Subjek menyatakan mendapatkan } \\
\text { mangah yang mirip } \\
\text { dengan masalah yang } \\
\text { dibrikan. }\end{array}$ \\
$\begin{array}{l}\text { Subjek menyebutkan } \\
\text { metode/cara yang } \\
\text { berhasil digunakan } \\
\text { untuk menyelesaikan } \\
\text { masalah yang dulu } \\
\text { pernah diberikan. } \\
\text { - Subjek menyusun } \\
\text { rencana penyelesaian } \\
\text { untuk masalah yang } \\
\text { diberikan saat ini } \\
\text { berdasarkan cara yang } \\
\text { telah berhasil } \\
\text { diterapkan. }\end{array}$ \\
\hline $\begin{array}{l}\text { Menghubungkan } \\
\text { konsep-konsep } \\
\text { yang ada pada } \\
\text { masalah yang }\end{array}$ & $\begin{array}{l}\text { Subjek menghubungkan } \\
\text { konsep-konsep pada } \\
\text { masalah yang dulu dengan } \\
\text { masalah yang saat ini }\end{array}$ \\
\hline
\end{tabular}

\begin{tabular}{|l|l|}
\hline diberikan & diberikan. \\
dengan konsep & \\
yang ada pada & \\
masalah yang & \\
mirip dan telah & \\
berhasil & \\
dipecahkan & \\
sebelumnya. & \\
\hline
\end{tabular}

c. Diskripsi berpikir subjek perempuan dalam melaksanakan rencana pemecahan maslah matematika

Tabel 7: Deskripsi berpikir subjek perempuan dalam melaksanakan rencana pemecahan masalah matematika

\begin{tabular}{|l|l|}
\hline \multicolumn{2}{|c|}{ Fase Melaksanakan Rencana } \\
\hline \multicolumn{1}{|c|}{ Indikator } & \multicolumn{1}{c|}{ Deskripsi } \\
\hline $\begin{array}{l}\text { Melaksanakan } \\
\text { rencana yang } \\
\text { telah diusun } \\
\text { pada fase-2. }\end{array}$ & $\begin{array}{l}\text { Subjek melaksanakan } \\
\text { rencana pemecahan } \\
\text { masalah seperti yang telah } \\
\text { disusun sebelumnya, yaitu } \\
\text { menggunakan cara } \\
\text { campuran (eliminasi dan } \\
\text { substitusi) untuk } \\
\text { mendapatkan nilai setiap } \\
\text { variabel. }\end{array}$ \\
\hline $\begin{array}{l}\text { Menjelaskan } \\
\text { alasan langkah } \\
\text { penyelesaian } \\
\text { dapat } \\
\text { diterapkan. }\end{array}$ & $\begin{array}{l}\text { Subjek menjelaskan alasan } \\
\text { langkah penyelesaian } \\
\text { dapat diterapkan. }\end{array}$ \\
\hline
\end{tabular}

d. Diskripsi berpikir subjek perempuan dalam memeriksa solusi yang diperoleh

Tabel 8: Deskripsi berpikir subjek perempuan dalam memeriksa solusi yang diperoleh

\begin{tabular}{|c|c|}
\hline \multicolumn{2}{|c|}{ Fase Memeriksa Kembali } \\
\hline Indikator & Deskripsi \\
\hline
\end{tabular}




\begin{tabular}{|c|c|}
\hline $\begin{array}{l}\text { Memeriksa } \\
\text { jawaban yang } \\
\text { diperoleh dengan } \\
\text { memperhatikan } \\
\text { apakah langkah } \\
\text { yang diterapkan } \\
\text { sudah sesuai } \\
\text { dengan prosedur } \\
\text { yang } \\
\text { direncanakan. }\end{array}$ & $\begin{array}{l}\text { Subjek mensubstitusikan } \\
\text { nilai dari setiap variabel } \\
\text { diperoleh ke } \\
\text { persamaan/informasi } \\
\text { yang ada pada masalah } \\
\text { yang diberikan. }\end{array}$ \\
\hline $\begin{array}{l}\text { Memeriksa } \\
\text { apakah jawaban } \\
\text { yang diperoleh } \\
\text { telah menjawab } \\
\text { permasalahan } \\
\text { yang diberikan. }\end{array}$ & $\begin{array}{l}\text { Subjek mengingat } \\
\text { kembali apa yang } \\
\text { ditanyakan dan } \\
\text { mencocokkannya dengan } \\
\text { jawaban yang } \\
\text { diperolehnya. }\end{array}$ \\
\hline
\end{tabular}

\section{Simpulan}

Berdasarkan hasil analisis data dan validasi, maka dapat disimpulkan bahwa

\section{Subjek Laki-Laki}

Subjek Laki-laki dalam memahami masalah yaitu menuliskan apa yang diketahui menggunakan bahasa simbol dan yang ditanyakan menggunakan bahasa verbal, menyajikan konsep bilangan ke dalam bentuk aljabar, serta menyatakan bilangan tiga angka yang dicari ke dalam bentuk aljabar berdasarkan aturan nilai tempat. Ketika menyusun rencana, subjek mengingat masalah lain yang telah berhasil dipecahkan dan mirip dengan masalah yang diberikan, serta menghubungkan konsep-konsep yang ada pada kedua masalah tersebut. Pada saat melaksanakan rencana pemecahan masalah, subjek tidak terikat dengan cara yang telah disusun pada fase sebelumnya, tidak menjelaskan alasan langkah-langkah penyelesaian dapat diterapkan dan menyadari bahwa jawaban dari masalah yang diberikan merupakan gabungan dari nilai setiap variabel. Sedangkan ketika memeriksa kembali, subjek mensubstitusikan hasil yang diperoleh ke persamaan/informasi yang ada pada masalah yang diberikan.

\section{Subjek Perempuan}

Subjek perempuan dalam memahami masalah yaitu mengungkapkan apa yang diketahui dan ditanyakan dengan menggunakan bahasa simbol, menyajikan konsep bilangan dan bilangan tiga angka yang dicari ke dalam bentuk aljabar. Sedangkan ketika menyusun rencana, subjek mengingat masalah lain yang telah berhasil dipecahkan dan mirip dengan masalah yang diberikan, dan menghubungkan konsep-konsep yang ada pada kedua masalah tersebut. Begitu juga ketika melaksanakan rencana pemecahan masalah, subjek melaksanakan rencana pemecahan masalah seperti yang telah disusun sebelumnya dengan menggunakan cara campuran (eliminasi dan substitusi) dan menjelaskan alasan langkah penyelesaian dapat diterapkan. Kemudian, ketika memeriksa kembali, subjek mensubstitusikan hasil yang diperoleh ke persamaan/informasi yang ada pada masalah yang diberikan serta mengingat kembali apa yang ditanyakan dan mencocokkannya dengan jawaban yang diperolehnya.

\section{Daftar Pustaka}

Dewiyani. 2012. The Thinking Process Profile The Students of Informatics System Departement in Solving The Mathematics Problem Based on The Personality Type and Gender. Proceeding. hal 1-10. STIKOM Surabaya.

Depdiknas. 2006. Peraturan Menteri Pendidikan Nasional Nomor 22 Tahun 2006 tentang Standar Isi Untuk Satuan Pendidikan Dasar dan Menengah. Jakarta: Depdiknas

Hudojo, Herman. 2001. Pengembangan Kurikulum dan Pembelajaran Matematika. Malang. Jurusan 
Pendidikan FMIPA Universitas Negeri Malang

Miles, B.M \& Huberman. 1992. Analisis Data Kualitatif. Jakarta: Universitas Indonesia Press.

Pimta, S., Tayruakham, S. dan Nuangchalerm, P. 2009. Factors Influencing Mathematic Problem-Solving Ability of Sixth Grade Students. Journal of Social Sciences. Vol 5, No 4, pp 381 - 385.

Polya, G. 1973. How to Solve It. Second Edition. Princeton University Press. Princeton, New Jersey.

Siswono, Tatag Y.E. 2008. Model Pembelajaran Matematika Berbasis Pengajaran dan Pemecahan Masalah untuk Meningkatkan Kemampuan Berpikir Kreatif. Surabaya: Unesa Press.

Solso, R.L. 2008. Psikologi Kognitif. Edisi kedelapan. Jakarta: Erlangga.

Sumadi Suryabrata. 2010. Psikologi Kepribadian. Raja Grafindo Persada. Jakarta.

Sugiyono, 2010. Memahami Penelitian Kualitatif. Bandung: Alfabeta 
Tahun XI, No. 20, April 2015 